University of Nebraska - Lincoln

DigitalCommons@University of Nebraska - Lincoln

Nebraska Beef Cattle Reports

Animal Science Department

2020

\title{
Evaluation of Masters Choice Corn Silage on Growing Steer Performance
}

\author{
Jiehua Xiong \\ University of Nebraska - Lincoln \\ Bradley M. Boyd \\ University of Nebraska - Lincoln \\ Levi McPhillips \\ University of Nebraska - Lincoln, levi.mcphillips@unl.edu \\ Kyle Vosburgh \\ University of Nebraska - Lincoln \\ Galen E. Erickson \\ University of Nebraska - Lincoln, gerickson4@unl.edu
}

Follow this and additional works at: https://digitalcommons.unl.edu/animalscinbcr

Part of the Large or Food Animal and Equine Medicine Commons, Meat Science Commons, and the Veterinary Preventive Medicine, Epidemiology, and Public Health Commons

Xiong, Jiehua; Boyd, Bradley M.; McPhillips, Levi; Vosburgh, Kyle; and Erickson, Galen E., "Evaluation of Masters Choice Corn Silage on Growing Steer Performance" (2020). Nebraska Beef Cattle Reports. 1055. https://digitalcommons.unl.edu/animalscinbcr/1055

This Article is brought to you for free and open access by the Animal Science Department at DigitalCommons@University of Nebraska - Lincoln. It has been accepted for inclusion in Nebraska Beef Cattle Reports by an authorized administrator of DigitalCommons@University of Nebraska - Lincoln. 


\section{Evaluation of Masters Choice Corn Silage on Growing Steer Performance}

\author{
Jiehua Xiong \\ Bradley M. Boyd \\ Levi McPhillips \\ Kyle Vosburgh \\ Galen E. Erickson
}

\section{Summary with Implications}

A growing study evaluated three corn silage hybrids on growing steer performance. The three hybrids were: a conventional hybrid-Farm Choice (CON) commonly grown in Eastern Nebraska which served as the control, Masters Choice hybrids MCT6365 RIB (MC1) selected to improve fiber and starch digestion and MCT6733 GT3000 (MC2) that has been selected to improve fiber digestion in cattle. Relative to CON, feeding hybrid MC1 resulted in similar DMI, but numerically increased ADG which significantly improved $F: G$ compared to CON. Feeding MC2 led to greater DMI, similar ADG, and poorer (greater) F:G compared to CON. Feeding Masters Choice hybrid MCT6365 RIB (MC1) corn silage at 80\% of the diet DM likely improved digestion and energy availability to the steers, which allowed greater $A D G$ and improved F:G, while the opposite was true for MC2. Differences in hybrids exist when fed to growing cattle at $80 \%$ of the diet.

\section{Introduction}

Previous research has shown an economic incentive to feeding cattle diets with elevated levels of corn silage when feed costs are high. When increased levels of corn silage are fed in corn-based finishing diets, NEm and NEg values of the ration are depressed. In recent studies completed at UNL, feeding 30 to $45 \%$ corn silage was more economical than lower silage inclusions, despite slightly poorer feed conversions. Methods that improve feed conversion when silage is elevated in diets

(c) The Board Regents of the University of Nebraska. All rights reserved. will make corn silage even more logical for backgrounding and feeding operations. Hybrids may be selected for differences in traits that may lead to better digestion, which should impact performance. Most previous evaluations of hybrid impact on corn silage use by beef and dairy cattle relies on laboratory testing. Those techniques may or may not predict actual performance when fed.

Therefore, the objective of this experiment was to evaluate two Masters Choice hybrids that have been selected to improve fiber plus starch digestion (MC1) and fiber digestion (MC2) in cattle (based on laboratory assays). These Masters Choice hybrids were compared to a hybrid commonly grown in Eastern Nebraska.

\section{Procedure}

Three hybrids of corn silage were grown and harvested at the Eastern Nebraska Research and Extension Center (ENREC) near Mead, NE. The three hybrids were a hybridFarm Choice (CON) commonly grown in Eastern Nebraska which served as the control, Masters Choice hybrids MCT6365 RIB (MC1) and MCT6733 GT3000 (MC2) that have been selected to improve fiber plus starch digestion (MC1) and fiber digestion (MC2) in cattle. Corn silage was targeted at $37-38 \%$ DM for green chop at harvesting and was harvested from Aug $27^{\text {th }}$ through Aug 29 ${ }^{\text {th }}, 2018$. Corn silages were stored in Silage Bags (Up North Plastics, Cottage Grove, MN) on a concrete pad until the initiation of the trial on Feb 13, 2019. Corn silage samples were collected for fermentation analysis prior to, middle, and end of the growing trial to ensure proper ensiling. All feeds were sampled weekly for DM and monthly composites analyzed for nutrients. Weekly corn silage samples were sent to commercial lab for yeast and mold counts.

An 84-day growing trial was conducted utilizing 288 crossbred steers (initial BW $=667 \pm 27 \mathrm{lb}$ ). All steers were limit-fed a common diet consisting of a 50:50 blend of alfalfa hay and SweetBran (Cargill, Blair, $\mathrm{NE}$ ) on a DM basis at $2 \%$ of BW for five days prior to trial initiation to minimize variation in gut fill. Following five days of limit feeding, steers were weighed for two consecutive days and the two-day weights averaged for initial BW. Cattle were stratified by BW (two blocks: light and heavy) and assigned randomly to pens with 12 head per pen. Pens were assigned randomly to one of the three treatments, with 8 pens per treatment. Steers were implanted with Ralgro (Merck Animal Health) during initial processing.

The three treatments (Table 1) were set up in a generalized randomized block design. All diets (DM basis) included 15\% modified distillers grains plus solubles (MDGS), $5 \%$ supplement, and $80 \%$ of respective corn silage for that treatment (CON, MC1 or MC2). Monensin was added in the supplement to supply $200 \mathrm{mg} /$ steer daily of Rumensin (Elanco Animal Health). Diets were formulated to ensure protein and nutrient requirements were met so any performance differences would be due to energetic differences between the different silage treatments. Steers were fed once daily in the morning and bunks were scooped and orts weighed as necessary and at the end of the growing trial to adjust for DMI. Ending BW was collected similar to initial BW with steers limit-fed at $2 \%$ of BW of 50:50 alfalfa hay and SweetBran diet for five days and weighed for two consecutive days.

Performance data (BW, DMI, ADG and F:G) were analyzed using the MIXED procedure of SAS 9.4 (SAS Institute, Inc., Cary, NC, USA) with pen serving as experimental unit. Block was included in the model as a fixed effect.

\section{Results}

After fermentation, DM declined slightly to $35-36 \%$ (Table 2). The fermentation analysis of the three corn silage hybrids indicated adequate and similar ensiling occurred between hybrids as $\mathrm{pH}$ was below 
Table 1. Diets (DM basis) fed to growing steers for 84 days to evaluate the use of Masters Choice silage or conventional hybrid.

\begin{tabular}{|c|c|c|c|}
\hline \multirow[b]{2}{*}{ Ingredients, \% } & \multicolumn{3}{|c|}{ Treatment $^{1}$} \\
\hline & $\mathrm{CON}$ & MC1 & MC2 \\
\hline Corn Silage-CON & 80 & - & - \\
\hline Corn Silage-MC1 & - & 80 & - \\
\hline Corn Silage-MC2 & - & - & 80 \\
\hline MDGS $^{2}$ & 15 & 15 & 15 \\
\hline Supplement ${ }^{3}$ & 5 & 5 & 5 \\
\hline \multicolumn{4}{|c|}{$\begin{array}{l}\text { CON, corn hybrid of Farm Choice silage containing diet serves as control; MC1, corn hybrid of MCT6365 RIB silage contain- } \\
\text { ing diet, selected for greater fiber + starch digestion; MC2, corn hybrid of MCT6733 GT3000 silage containing diet, selected fo } \\
\text { greater fiber digestion }\end{array}$} \\
\hline \multicolumn{4}{|c|}{${ }^{2}$ MDGS, modified distillers grains plus solubles } \\
\hline \multicolumn{4}{|c|}{$\begin{array}{l}{ }^{3} \text { Supplement consisted of } 2.79 \% \text { fine ground corn, } 1.21 \% \text { limestone, } 0.125 \% \text { tallow, } 0.50 \% \text { urea, } 0.30 \% \text { salt, } 0.05 \% \text { trace mineral } \\
\text { package ( } 10 \% \mathrm{Mg}, 6 \% \mathrm{Zn}, 4.5 \% \mathrm{Fe}, 2 \% \mathrm{Mn}, 0.05 \% \mathrm{Cu}, 0.3 \% \mathrm{I} \text { and } 0.05 \% \mathrm{Co}), 0.015 \% \text { vitamin A-D-E package ( } 1,500 \mathrm{IU} \text { of } \\
\text { vitamain A, 3,000 IU of vitamin D, } 3.7 \mathrm{IU} \text { of vitamin E) as percentages of the final diets (DM basis) and Rumensin to provide } \\
200 \mathrm{mg} / \mathrm{steer} \text { daily (assuming a DMI of } 22 \mathrm{lb} \text { ) }\end{array}$} \\
\hline
\end{tabular}

Table 2. Nutrient and fermentation analysis of three corn silage hybrids

\begin{tabular}{|c|c|c|c|c|}
\hline \multirow[b]{2}{*}{ Item $^{2}$} & \multirow[b]{2}{*}{ Goal } & \multicolumn{3}{|c|}{ Hybrids $^{1}$} \\
\hline & & $\mathrm{CON}$ & MC1 & MC2 \\
\hline $\mathrm{DM}^{3}, \%$ & & 35.67 & 36.72 & 36.11 \\
\hline $\mathrm{CP}, \%$ of DM & & 8.10 & 8.22 & 8.48 \\
\hline $\mathrm{NDF}, \%$ of DM & & 33.43 & 34.20 & 36.60 \\
\hline $\mathrm{ADF}, \%$ of $\mathrm{DM}$ & & 21.37 & 20.17 & 22.00 \\
\hline $\mathrm{pH}$, as sampled & $<4$ & 3.97 & 4.00 & 3.93 \\
\hline Lactic Acid, \% of DM & $>4$ & 4.94 & 3.82 & 4.28 \\
\hline Acetic Acid, \% of DM & $<3$ & 3.58 & 4.85 & 2.91 \\
\hline Lactic/Acetic Ratio & $1.6-3.0$ & 1.38 & 0.84 & 2.34 \\
\hline Propionic Acid, \% of DM & $<1$ & 0.80 & 1.18 & 0.46 \\
\hline Butyric Acid, \% of DM & $<0.1$ & 0.06 & 0.11 & 0.01 \\
\hline IsoButyric, \% of DM & & 0.01 & 0.01 & 0.01 \\
\hline Total Acids, $\%$ of DM & $7.0-12.0$ & 9.39 & 9.97 & 7.66 \\
\hline Ammonia, CPE\% of DM & & 0.64 & 0.73 & 0.53 \\
\hline Ammonia- $\mathrm{N}, \%$ of Total $\mathrm{N}$ & $8.0-15.0$ & 7.89 & 9.01 & 6.00 \\
\hline VFA Score & $6.0-10.0$ & 7.61 & 7.09 & 7.35 \\
\hline \multicolumn{5}{|c|}{$\begin{array}{l}{ }^{1} \text { CON, corn hybrid of Farm Choice silage serves as control; MC1, corn hybrid of MCT6365 RIB silage, selected for greater fiber } \\
\text { + starch digestion; MC2, corn hybrid of MCT6733 GT3000 silage, selected for greater fiber digestion }\end{array}$} \\
\hline $\begin{array}{l}2 \text { All values except DM content wer } \\
\text { feeding period }\end{array}$ & es of three sam & efore the & , at the 1 & the end \\
\hline
\end{tabular}

Table 3. Effect of Masters Choice corn silage hybrids on growing performance of beef steers.

\begin{tabular}{|c|c|c|c|c|c|}
\hline \multirow[b]{2}{*}{ Variable } & \multicolumn{3}{|c|}{ Treatments $^{1}$} & \multirow[b]{2}{*}{ SEM } & \multirow[b]{2}{*}{$P$-value } \\
\hline & $\mathrm{CON}$ & $\mathrm{MC1}$ & MC2 & & \\
\hline Initial BW, lb & 667 & 667 & 667 & 0.7 & 0.99 \\
\hline Ending BW, lb & $1001^{\mathrm{ab}}$ & $1011^{\mathrm{a}}$ & $995^{\mathrm{b}}$ & 5.1 & 0.10 \\
\hline DMI, lb/d & $22.7^{\mathrm{b}}$ & $22.5^{\mathrm{b}}$ & $24.0^{\mathrm{a}}$ & 0.141 & $<0.01$ \\
\hline ADG, lb & $3.98^{\mathrm{ab}}$ & $4.11^{\mathrm{a}}$ & $3.92^{\mathrm{b}}$ & 0.058 & 0.09 \\
\hline$F: G$ & $5.71^{\mathrm{b}}$ & $5.48^{\mathrm{a}}$ & $6.13^{\mathrm{c}}$ & 0.065 & $<0.01$ \\
\hline
\end{tabular}

a-c Means within a row with different superscripts differ $(P<0.05)$.

${ }^{1}$ CON, corn hybrid of Farm Choice silage containing diet serves as control; MC1, corn hybrid of MCT6365 RIB silage containing diet, selected for greater fiber + starch digestion; MC2, corn hybrid of MCT6733 GT3000 silage containing diet, selected for greater fiber digestion
4.0 and total acids was at least $7.0 \%$. Fiber, protein, and DM contents appear similar but silage storage is not replicated so nutrient differences are not analyzed statistically.

Ending BW and ADG tended $(P \leq 0.10)$ to be impacted by silage hybrid (dietary treatment) while DMI and F:G were impacted by corn silage hybrid fed $(P<0.01)$. Ending BW of steers fed $\mathrm{MC} 1$ tended to be greater than $\mathrm{CON}(P=0.15)$ and was greater than MC2 $(P=0.04)$, while ending BW of steers fed MC2 and CON were not significantly different $(P=0.46$, Table 3$)$. Intake of steers fed $\mathrm{MC} 1$ did not differ $(P=0.28)$ from steers fed CON, whereas steers fed MC2 had greater $(P<0.01)$ DMI compared to $\mathrm{CON}$ and MC1. Average daily gain (ADG) of steers fed $\mathrm{MC} 1$ tended to be greater than CON steers $(P=0.14)$ and was greater than steers fed MC2 $(P=0.03)$, with no difference between steers fed MC2 and CON $(P=0.45)$. With numerically lower intake and greater ADG, F:G of steers fed $\mathrm{MC1}$ was improved $(P \leq 0.02)$ compared to steers fed CON and MC2. Steers fed MC2 had the poorest $\mathrm{F}: \mathrm{G}$ which was greater than steers fed $\mathrm{CON}(P<0.01)$.

The yeast count (Table 4 ) of the three corn silage samples during the feeding period stayed low and constant with no difference between hybrids. The mold count of MC2 corn silage tended to be increased as time went and was greater than hybrids $\mathrm{CON}$ and $\mathrm{MC1}$, especially in week 6, 7 and 8 of the feeding periods. Two bags of each silage were ensiled due to quantity. On week 9, the MC2 bag was switched to the new bag. The mold count of CON and MC1 corn silage were similar through the feeding period. Mold, due to storage conditions in this study, might impact nutrient content and digestibility of corn silage thus compromise animal performance, but was unlikely in this trial.

\section{Conclusions}

Feeding Masters Choice corn silage hybrid MCT6365 RIB (MC1) that has been selected for improved starch and fiber digestion at $80 \%$ of the diet DM improved ADG and F:G when compared to the other corn silage hybrids grown in Eastern Nebraska. Slightly less intake, greater ADG and improved feed efficiency indicates digestion and energy availability of corn 
Table 4. Yeast and Mold counts ${ }^{1}$ of corn silage sample on different date

\begin{tabular}{lcccccc}
\hline & \multicolumn{7}{c}{ Hybrids $^{2}$} \\
\cline { 2 - 7 } Sample Date $^{3}$ & \multicolumn{2}{c}{ CON } & \multicolumn{2}{c}{ MC1 } & \multicolumn{3}{c}{ MC2 } \\
\cline { 2 - 7 } Yeast & Mold & Yeast & Mold & Yeast & Mold \\
\hline 2/18/2019 & $<10$ & $<10$ & $<10$ & $<10$ & $<10$ & $<10$ \\
$2 / 25 / 2019$ & $<10$ & $<10$ & $<10$ & $<10$ & $<10$ & $<10$ \\
$3 / 4 / 2019$ & $<10$ & $<10$ & $<10$ & 10 & $<10$ & 50 \\
$3 / 11 / 2019$ & $<10$ & 20 & $<10$ & 40 & $<10$ & 80 \\
$3 / 18 / 2019$ & $<10$ & $<10$ & $<10$ & $<10$ & $<10$ & 10 \\
$3 / 25 / 2019$ & $<10$ & $<10$ & $<10$ & $<10$ & $<10$ & 2200 \\
$4 / 1 / 2019$ & $<10$ & $<10$ & $<10$ & $<10$ & $<10$ & 1800 \\
$4 / 8 / 2019$ & $<10$ & $<10$ & $<10$ & $<10$ & $<10$ & 300 \\
$4 / 15 / 2019$ & $<10$ & 30 & $<10$ & $<10$ & $<10$ & $<10$ \\
$4 / 22 / 2019$ & $<10$ & 20 & $<10$ & 120 & $<10$ & $<10$ \\
$4 / 29 / 2019$ & $<10$ & 40 & $<10$ & 20 & $<10$ & 60 \\
$5 / 6 / 2019$ & $<10$ & $<10$ & $<10$ & 10 & $<10$ & $<10$ \\
\hline
\end{tabular}

${ }^{1}$ All results are reported on an AS RECEIVED basis (cfu/g), cfu = colony forming unit

${ }^{2} \mathrm{CON}$, corn hybrid of Farm Choice silage serves as control; MC1, corn hybrid of MCT6365 RIB silage, selected for greater fiber + starch digestion; MC2, corn hybrid of MCT6733 GT3000 silage, selected for greater fiber digestion

${ }^{3}$ MC2 sampled on and before 4/8/2019 were before switching to backup storage bag, MC2 sampled on and after 4/15/2019 were from the backup silage bag; samples of $\mathrm{CON}$ and $\mathrm{MC1}$ were all from the original bags silage was improved when cattle were fed $\mathrm{MC1}$, which could be beneficial in reducing total feed cost and make corn silage feeding more appealing to cattle feeders. These data suggest that corn hybrid selection can impact cattle performance when fed.

Jiehua Xiong, graduate student

Bradley M. Boyd, research technician

Levi McPhillips, research technician

Kyle Vosburgh, Masters Choice

Galen E. Erickson, professor, Animal Science, University of Nebraska-Lincoln 